\title{
Deformations of the mining area surface as a result of exploitation with sealing of caving gobs
}

\author{
Violetta Sokoła-Szewioła, Aleksandra Mierzejowska \& Marian Poniewiera \\ Silesian University of Technology
}

\begin{abstract}
SUMMARY: In Polish conditions of conducting underground hard coal mining in the past, in order to limit the negative impacts of conducted mining, systems with gobs filling with dry or hydraulic backfill were used. In recent years, this method of managing the floor has been abandoned, while as part of fire prevention and in order to enable waste placement in old gobs, caving mining with sealing gobs is used. It seems that this solution also results in a reduction in the amount of surface deformation. The authors presented in the article the results of own research on the subject matter. The research covered the area of one of the mines conducting exploitation in the area of the Upper Silesian Coal Basin. It was determined that the use of exploitation with sealing caving gobs reduces the subsidence coefficient, and the values of the subsidence observed in the analyzed area may be even $25 \%$ lower than when conducting exploitation without sealing and the strain extreme values over time can be up to $40 \%$ smaller.
\end{abstract}

Keywords: deformation, sealing, caving gobs, subsidence

\section{INTRODUCTION}

Underground mining of useful mineral deposits causes deformations of the rock mass and the surface area. The values of these quantities depend primarily on the geological structure of the rock mass, mechanical properties of the rocks forming the rock mass, as well as the exploitation systems used and methods of filling the post-mining void. The above can be described using geological, geomechanical and mining factors. Among geological factors, in the conditions of underground hard coal mining in Poland, the exploitation depth, the thickness of the overburden rocks above carbon, the dip of the seam and layers in the rock mass, the presence of tectonic dislocations. Geomechanical factors determine the rock mass's ability to transfer the influence of mining exploitation. The ability to measure this can be the rock mass parameter, depending on the type and mechanical properties of the rocks, such as compressive and tensile strength, deformation properties and the ratio of Carboniferous rock thickness to the overburden, and the extent of the rock mass violation by previous exploitation. The most important mining factors include the dimensions and shape of mining fields, mutual location of fields and mining fronts, thickness of seams extraction, mining systems and methods of gobs filling, velocity and conditions for moving fronts as well as the order of exploitation and cleanliness of mining of deposit and activation of old gobs (Szpetkowski, 1995). Appropriate mining prevention is used to limit the negative impacts of conducted mining. In this case, it is important, among others, to know the description of the effects of exploitation and to be able to determine optimal exploitation solutions on the basis of the predicted effects of designed exploitations. Limiting the value of rock mass and surface deformation can be obtained by 
changing the thickness of exploitation and using an appropriate way of liquidation of gobs, which is characterized by the subsidence coefficient $a$, also called the exploitation coefficient. Its value determines the ratio of the largest subsidence observed to the thickness of the selected seam or layer. For the conditions of conducting mining in the region of the Upper Silesian Coal Basin (USCB), if the deposit is selected with a fall of roof, its value is from about 0.7 with a predominance of strong rocks in overburden to 0.9 with a weak overburden. An additional factor affecting the value of the coefficient $a$ is the degree of rock mass violation through previous exploitations. Experiments have shown that in the case when the value of the maximum subsidence is less than the thickness of the mining, the parameter $a$ takes the value $<1$, with the value of the subsidence equal to the thickness of exploitation $a$ takes the value 1 , in the case of the maximum subsidence value greater than the thickness of the exploitation $a$ reaches the value $>$ than 1. This variation depends on the type of rock in the rock mass, rock compactness and divisibility into blocks. In the case of exploitation of a deposit with backfill, the value of the coefficient is reduced. The process of deposit deformation is milder and the effects of exploitation on the surface are quantitatively smaller. Until now, in the conditions of exploitation of hard coal deposits in the Upper Silesian Coal Basin region, a hydraulic backfill was used, which was a mixture of sand and water, being a means of transport, dry backfill, which was rock material supplied from the surface or from mining excavations, a hardened backfill, which was a multi-component mixture, which hardens after some time, obtaining a certain compressive strength, and to the binding material was added e.g. gypsum or cement. The amount of surface subsidence depends in this case primarily on the compressibility of the backfill, determined by the change in layer height under load. It was found that regardless of the mining system, the observed surface deformations were even 4 times smaller than those caused by exploitation with fall of roof (Ostrowski, 2015). Table 1 presents the approximate value of the subsidence coefficient $a$ for hard coal mining in the Upper Silesian Coal Basin region, depending on the method of gobs filling.

Currently, exploitation with backfill is not used in Polish hard coal mines, while as part of fire prevention and in order to allow waste to be deposited in old gobs, exploitation with sealing caving gobs is used. Studies indicating the impact of using this type of gobs filling on the value of surface deformation are few, so the authors in this paper presented the results of their own research on this subject. The research was conducted in the area of one of the hard coal mines conducting mining in the Upper Silesian Coal Basin area. To determine the value of parameter $a$ and to develop computer simulations of the value of deformation indicators, the geometricintegral theory of forecasting the impacts of mining exploitation on the surface was used, data on mining exploitation performed in the analyzed region and the results of subsidence measurements made using geodetic methods. The research abandoned the method allowing the determination of the coefficient $a$ based on the results of measurements of maximum subsidence, due to the fact that such observations were not available due to the location of the measuring points. The values of surface deformation indicators were determined for two computational areas. The research areas were selected so that in the analyzed period the impact of other exploitation on the values of subsidence found by geodetic measurements in these regions was not observed.

Table 1. Approximate value of the subsidence coefficient a in hard coal mining in the Upper Silesian Coal Basin area.

\begin{tabular}{ll}
\hline Methods of gobs filling & Subsidence coefficient $a$ \\
\hline Fall of roof & $0,7-0,85$ \\
Dry full backfill & $0,5-0,6$ \\
Dry pneumatic backfill & $0,4-0,5$ \\
Hydraulic sand backfill & $0,15-0,25$ \\
Hydraulic crushed stone backfill & 0,3 \\
Partial exploitation with belts (50\% with hydraulic backfill) & $0,02-0,03$ \\
Partial exploitation with belts (50\% with fall of roof) & 0,1 \\
\hline
\end{tabular}

Source: Protection of building structures in mining areas. (Collective work edited by Kwiatek. 1998). 


\section{PREVIOUS STUDIES OF THE IMPACT OF SEALING GOBS ON VALUES OF DEFORMATION}

The problem of sealing caving gobs as part of fire prevention in Poland was the subject of research conducted at the Silesian University of Technology. The degree of filling caving gobs and sealing caving gobs was determined using backfill mixture of dusts (Plewa et al, 2008). The degree of gobs filling was determined as the ratio of the volume of waste deposited in gobs to the volume of gobs defined as the volume of the exploited seam. The degree of sealing was determined as the ratio of the volume of deposited waste to the theoretical absorbency of caving gobs. The theoretical absorbency of gobs was determined by the product of the gobs absorbency coefficient and the volume of the exploited seam. In work (Piotrowski and Mazurkiewicz, 2006), the authors based on the analysis of 39 cases determined that the absorbency of gobs can range from 0.07 to 0.27 . Research on the impact of sealing caving gobs on the value of the surface deformations presented in work (Zych et al, 1993) showed that the estimated value of the subsidence coefficient in the case of sealing gobs may be reduced by 0.1 compared to the exploitation without sealing gobs. In 2019, T. Rutkowski determined that in the area of exploitation carried out in the area of the Ruda-Ruch Pokój coal mine, the value of the coefficient $a$ when exploiting with sealing caving gobs was less by 0.07 than the coefficient $a$ determined for exploitation with fall of roof (Rutkowski, 2019). Among foreign research in the field of the above issue can be mentioned work (Yu Yang et al). In the field of sealing caving gobs, a number of studies were also carried out, the main purpose of which was to determine the impact of organic compounds on the parameters of mixtures injected into caving gobs. As a result of research carried out recently, relevant from the point of view of the subject discussed, among others, criteria were selected for the selection of waste materials in terms of their granulation, improvement of the ability to increase penetration in caving debris and the degree of filling and sealing caving gobs (Świnder, 2014).

\section{THE METHOD OF DESCRIBING THE SURFACE DEFORMATION DUE TO MINING EXPLOITATION USED IN THE RESEARCH}

Research on the effects of mining exploitation on the rock mass and the surface are conducted in several basic directions (Litwiniszyn, 1969). In the first, the results of the research are empirical formulas, on the basis of which the predicted values of selected deformation indicators are determined. When considering the impact of mining exploitation on the rock mass and the surface, it is also possible to use methods based on deductive schemes, which include methods assuming that the rock mass is a stochastic medium, methods based on the assumptions of the theory of elasticity and plasticity, or based on geometric assumptions regarding the distribution of impacts. In theories based on geometrical assumptions regarding the distribution of extraction impact, called geometric-integral theories, each point on the surface or point inside the rock mass has been assigned a function describing the impact of extracting deposit volume with a unit surface area on this point, depending on the location of the extracted deposit volume relative to the subject point. These theories differ in the form of functions. Examples of such theory include, among others, works (bals, 1931/1932, Beyer, 1945). The most important works of Polish researchers include the works of S. Knothe (Knothe, 1953), W Budryk (Budryk, 1953), and T. Kochmański (Kochmański, 1949), as well as further modifications and extensions of these theories developed by J. Białek (Białek 2003), B. Dżegniuk (Dżegniuk, 1979), K. Greń (Greń, 1981), J. Zych (Zych, 1987), A. Sroka (Sroka, 1999), R. Hejmanowski (Hejmanowski, 2004), A. Kowalski (Kowalski, 2007). Among the numerous works in this field, one should also mention those that contain the results of research that allow to improve the accuracy of the description of the mining area surface deformation in time contained in the works (Białek and Sokoła-Szewioła, 2012, Sokoła-Szewioła and Kowalska-Kwiatek, 2013).

In order to make calculations in the research, which is the subject of the article, the geometric-integral theory of influences of S. Knothe (Knothe, 1953) was used, which was extended by W. Budryk in 1953 (Budryk, 1953). This theory was based on the normal Gaussian 
distribution of the effect of mining an elementary volume. The choice of theory was conditioned by several reasons, primarily the commonness of its application for forecasting the impact of exploitation in Polish mining and the possibility of using extensive computer packages developed at the Silesian University of Technology by J. Białek. These programs allow to make prognostic calculations with the presentation of results for individual points in tabular form - and in the form of deformation maps, and also allow the analysis to be carried out consisting in determining the parameters of forecasting theory based on the results of measurements of subsidence of the mining area over time and the gobs geometry corresponding to these measurements. The most important feature of the programs is to take into account the development of exploitation over time. The calculations used extensions of S. Knothe's theory formulas proposed by J. Białek. In the classical form of the theory (Knothe, 1953), the subsidence of $w_{k}$ at point $\mathrm{P}$, i.e. the vertical component of the rock mass displacement vector caused by the exploitation of the surface of the $S$ seam, is expressed by the formula:

$$
w_{k}=\iint_{S} \frac{a g}{r(z)^{2}} \exp \left(-\pi \frac{(\xi-x)^{2}+(\eta-y)^{2}}{r(z)^{2}}\right) d \xi d \eta
$$

where:

$w_{k}$ - final subsidence of point $\mathrm{P}$, calculated without taking into account the time delay, $x, y, z$ - coordinates of the calculation point,

$a$ - subsidence factor, depended on the method of the roof management,

$g$ - exploitation thickness of the seam or layer,

$S$-surface of the exploited seam, assuming that it is a function of time

$S=S(t)$,: then the subsidence is a function of time $w_{k}=w_{k}(x, y, z, \quad S(t))$, $\xi, \eta$ - coordinates of the element of $d S$ surface.

Impact dispersion radius:

$$
r(z)=\frac{h}{\operatorname{tg} \beta}\left(\frac{z-z_{0}}{h-z_{o}}\right)^{n}
$$

$\operatorname{tg} \beta$ - parameter of Knothe's theory,

$h$ - depth of the exploited element of the surface of $d S$ seam

$z$ - height of the calculation point above the element of $d S$ surface,

$z_{o}$ - parameter proposed by B. Drzęźla,

$n$ - exponent in the formula (assumed for these calculations $z_{o}=5 a g, n=0,665$ ).

The horizontal components of the displacement vector are calculated based on the Awierszyn hypothesis according to which the horizontal displacement at $\boldsymbol{P}$ is proportional to a certain constant $B$ and the dip $T$ :

- horizontal displacements in the direction of the $\mathrm{x}$ axis:

$$
u_{x k}=-B T_{x}=-B \frac{\partial w_{k}}{\partial x}
$$

- horizontal displacements in the direction of the y axis:

$$
u_{y k}=-B T_{y}=-B \frac{\partial w_{k}}{\partial y}
$$

$w_{k}$ - subsidence calculated from formula (1),

$B$ - horizontal strains factor.

The $B$ value was calculated by the formula developed by Popiołek and Ostrowski (Popiołek and Ostrowski, 1981) in the form: 


$$
B=0,32 r
$$

J. Białek's (Białek, 2003) formula adopted in the calculations takes the form:

$$
W_{k}=\left(1-a_{w}\right) w\left(r_{1}\right)+a_{w} w\left(r_{2}\right)-A_{o b r} \frac{5.3333 \cdot w\left(r_{1}\right) \cdot\left[r_{1} \gamma\left(r_{1}\right)\right]^{2}}{6.666 \cdot\left[0.5 \cdot w\left(r_{1}\right)+0.5 \cdot w\left(r_{2}\right)\right]^{2}+\left[r_{1} \gamma\left(r_{1}\right)\right]^{2}}
$$

where: $A_{o b r}$,- parameter including the asymmetry of the subsidence trough profile, $w\left(r_{1}\right)$, w $\left(\mathrm{r}_{2}\right)$ - subsidence calculated according to $\mathrm{S}$. Knothe's formula (1) for the radii of impacts scattering $r=r_{1}$ and $r=r_{2}$;

$\gamma\left(r_{1}\right)$ deformation calculated by the formula:

$$
\begin{gathered}
\gamma\left(r_{1}\right)^{2}=\left[0.25 \cdot r_{1} \cdot\left(\frac{\partial^{2} w\left(r_{1}\right)}{\partial x^{2}}+\frac{\partial^{2} w\left(r_{1}\right)}{\partial y^{2}}\right)\right]^{2}+\left(\frac{\partial w\left(r_{1}\right)}{\partial x}\right)^{2}+\left(\frac{\partial w\left(r_{1}\right)}{\partial y}\right)^{2} \\
a_{w}=0,4-1,25 A_{o b r} ; \\
r_{1}=\frac{h}{\operatorname{tg} \beta} F\left(A_{o b r}\right) ; r_{2}=2 r_{1}
\end{gathered}
$$

Table 2 shows the value of the $\mathrm{F}$ function.

Table 2. Values of the $\mathrm{F}$ function

\begin{tabular}{llllllll}
\hline$A_{\text {obr }}$ & 0 & 0,050 & 0,100 & 0,150 & 0,200 & 0,250 & 0,300 \\
\hline$F\left(A_{\text {obr }}\right)$ & 0,800 & 0,844 & 0,916 & 1,003 & 1,099 & 1,200 & 1,303 \\
\hline
\end{tabular}

Source: 4. Biatek J. Algorithms and computer programs for the prediction of mining ground deformation Silesian University of Technology, Gliwice 2003 (Białek, 2003)

In order to assess the impact of exploitation, the basic and most accurately described deformation ratio are subsidence. In order to describe the deformation process more accurately, derivative values of displacements, i.e. deformation, dip and curvature, are determined. Research focused on the analyzes of the mining area subsidence. In addition, the analyzes were performed for horizontal deformations due to the fact that they are the basic indicator significant for the impact of mining exploitation effects on objects located on the surface of the mining area. Horizontal strains were calculated by the formula in the general form:

$$
\varepsilon_{x k}=\frac{\partial}{x}\left(-B \frac{\partial w k}{\partial x}\right)
$$

\section{MATERIALS AND METHODS}

The research was carried out in the area of hard coal mine conducting exploitation in the area of the Upper Silesian Coal Basin. As a result of the analysis of exploitation data, two regions and time periods were identified for which detailed analyzes were carried out. In area I (exploitation of seam C), in the selected period, exploitation was carried out successively with three longwalls with sealing of caving gobs, using a mixture of flotation waste, flying ashes and water. Data on the sealing process is given in Table 3. The height of the mixture in 
Table 3. Data characterizing the sealing process.

\begin{tabular}{lllll}
\hline Seam & Longwall & $\begin{array}{l}\text { The volume of caving } \\
\text { gobs V }\left[\mathrm{m}^{3}\right]\end{array}$ & $\begin{array}{l}\text { The volume of the sealing } \\
\text { mixture }\left[\mathrm{m}^{3}\right]\end{array}$ & $\begin{array}{l}\text { The height of the mixture } \\
\text { in the excavation } M[\mathrm{~m}]\end{array}$ \\
\hline C- region I & C1 & 581824 & 24223 & 0,120735 \\
& C2 & 813622 & 31594 & 0,112611 \\
& C 3 & 1083136 & 28620 & 0,076627 \\
\hline
\end{tabular}

Source: own study

the excavation was determined assuming its even distribution. The volume of caving gobs was calculated based on mining data from the region.

In region II (exploitation of seam B) in the assumed period, two longwalls with fall of roof were exploited in succession. The research areas were selected so that the impact of exploitation carried out in other regions did not appear in the analyzed period. The availability of measurement results of observation $\mathrm{p}$

Points subsidence was also taken into account (in the analyzed area, above seam $\mathrm{C}$ - observation lines $\mathrm{a}, \mathrm{b}, \mathrm{c}$, in the analyzed area, above seam $\mathrm{B}$ - lines $d, e$ ). Mining and geological data of exploitation fields in the analyzed regions are presented in Table 4. The contours of the exploitation plots in the areas in question and the location of points of the observation lines are shown in Figures 1 and 2.

Further considerations were made using the geometric-integral theory of forecasting the impacts of mining exploitation on the surface, discussed in detail in Chapter 3. The calculations were carried out in the program of J. Białek in the following ranges:

- values of parameters of the theory $a, \operatorname{tg} \beta$ and $A_{o b r}$ were determined separately for research regions I and II,

- computer simulation of subsidence and horizontal strains for regions I and II using the determined parameters was developed,

- a computer simulation of subsidence and horizontal strains for region I was developed assuming the values of parameters determined for exploitation with fall of roof (region II).

The calculation results were presented in the form of subsidence increments maps and strain extreme values maps over time. The analyzes that are the subject of the research are described in chapter 6 .

Table 4. Mining and geological data of exploitation fields in the analyzed regions.

\begin{tabular}{|c|c|c|c|c|c|c|c|c|}
\hline Seam & Longwall & $\begin{array}{l}\text { Startup } \\
\text { date }\end{array}$ & End date & $\begin{array}{l}\text { Average } \\
\text { depth } \\
{[\mathrm{m}]}\end{array}$ & $\begin{array}{l}\text { Length } \\
\text { of long- } \\
\text { wall [m] }\end{array}$ & $\begin{array}{l}\text { Excavation } \\
\text { advance } \\
{[\mathrm{m}]}\end{array}$ & $\begin{array}{l}\text { Exploitation } \\
\text { thickness } \\
g[\mathrm{~m}]\end{array}$ & $\begin{array}{l}\text { Dip } \\
\text { of the } \\
\text { seam } \\
{[\mathrm{g}]}\end{array}$ \\
\hline \multicolumn{9}{|c|}{ Exploitation with sealing of caving gobs } \\
\hline \multirow[t]{3}{*}{ C- region I } & $\mathrm{C} 1$ & 1.09 .2011 & 31.03 .2012 & 825 & 245 & 799 & 2,90 & \multirow[t]{3}{*}{$2-7$} \\
\hline & $\mathrm{C} 2$ & 20.03.2012 & 30.10 .2012 & 840 & 240 & 1168 & 2,90 & \\
\hline & $\mathrm{C} 3$ & 1.10 .2012 & 31.08 .2013 & 862 & 250 & 1470 & 2,90 & \\
\hline \multicolumn{9}{|c|}{ Exploitation with fall of roof } \\
\hline \multirow[t]{2}{*}{ B- region II } & B1 & 15.07.2005 & 28.02 .2006 & 581 & 250 & 900 & 2,70 & \multirow[t]{2}{*}{$1-8$} \\
\hline & B2 & 15.10 .2006 & 31.07.2007 & 585 & 250 & 1082 & 2,80 & \\
\hline
\end{tabular}

Source: own study 


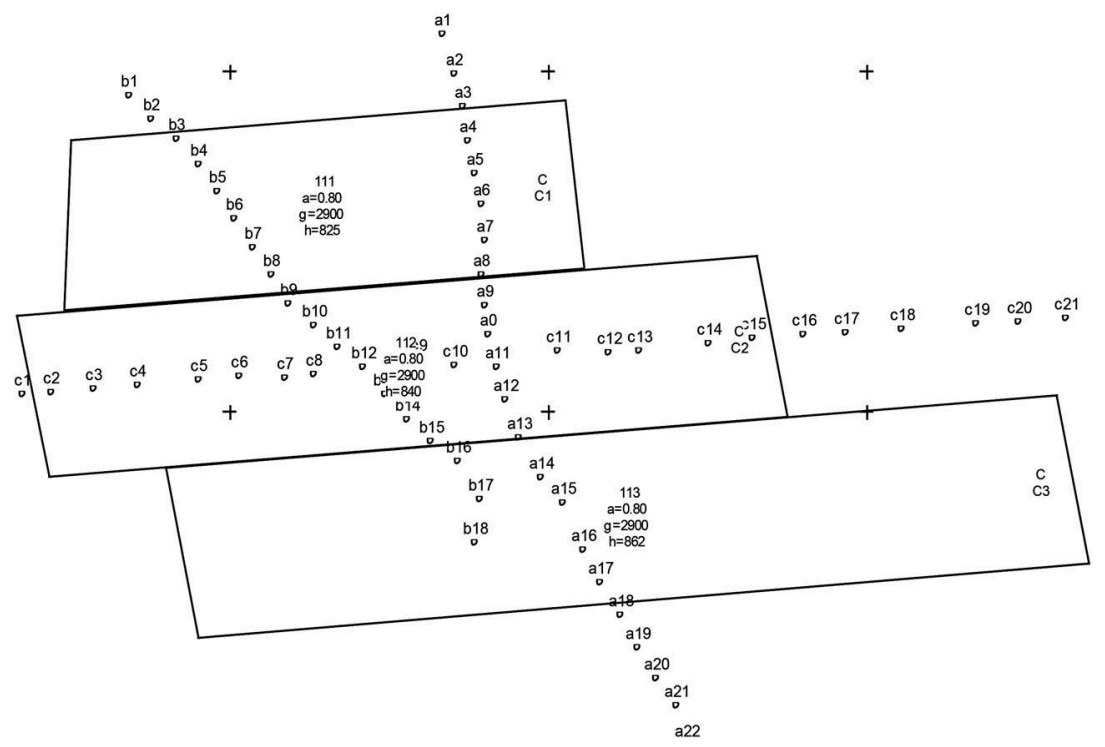

Figure 1. Contours of exploitation carried out in the region I (seam C) in the period under research and location of points of the observation lines - lines $a, b, c$.

Source: own study

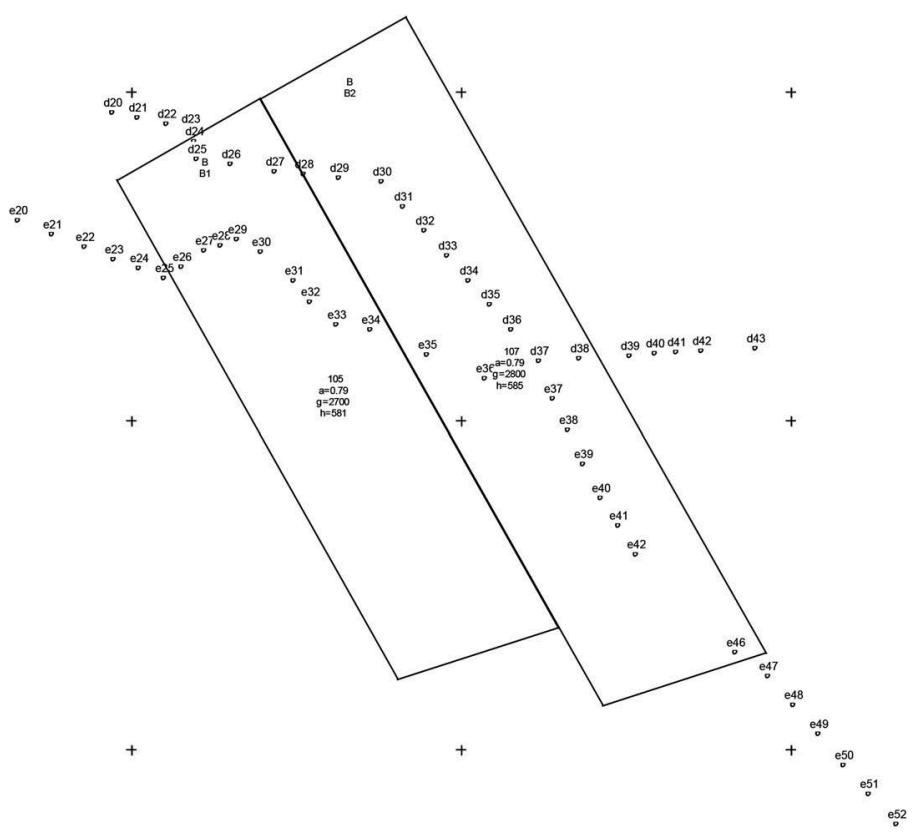

Figure 2. Contours of exploitation carried out in region II (seam B) in the period under research and location of points of the observation lines $d$ and $e$.

Source: own study 


\section{RESULTS}

The parameters of the established calculation model: $a, \operatorname{tg} \beta, A_{o b r}$ determined on the basis of geodetic measurements, geometry of exploitation fields, thickness and depth of exploitation are presented in Table 5. These parameters were determined based on the adjustment of the theoretical profile of the subsidence trough to the real trough using the least squares method. For the first region (exploitation of seam $\mathrm{C}$ ), the parameters were determined on the basis of the measured subsidence for three calculation variants. In the first variant, the parameters were determined after exploitation of the parcel $\mathrm{C} 1$ in seam $C$. In the next variants, the parameters were determined respectively, after exploitation of the parcels $\mathrm{C} 1$ and $\mathrm{C} 2$, and after exploitation of all the parcels, i.e. $\mathrm{C} 1$, $\mathrm{C} 2$ and $\mathrm{C} 3$. In the region II (seam B), the parameters were determined for the situation after exploitation of parcels B1 and B2.

The distribution of real subsidence and subsidence calculated by the formula (6) on the points of the measuring line $\mathrm{b}$ for the state after completing the selection of parcels $\mathrm{C} 1, \mathrm{C} 2, \mathrm{C} 3$ is shown in Figure 3.

The surface distribution of increments of the area subsidence and maximum strains extreme over the period covered by the research in regions I and II are shown in Figures 4, 5, 7 and 8. The spatial distribution of subsidence increments in the period mentioned above is presented in Figure 6.

Table 5. The results of matching theoretical subsidence to the subsidence determined by geodetic measurements on observation lines - determined parameter values.

\begin{tabular}{lllllll}
\hline Exploitation stage & $\operatorname{tg} \beta$ & $a$ & $A_{\text {obr }}$ & $\begin{array}{l}\text { Standard deviation } \\
{[\mathrm{mm}]}\end{array}$ & Correlation coefficient & $\begin{array}{l}W_{\max } \\
\text {-measured [m] }\end{array}$ \\
\hline $\begin{array}{l}\text { Fall of roof with sealing } \\
\text { C1 }\end{array}$ & 1,48 & 0,473 & 0,131 & 13,6 & & \\
C1 and C2 & 2,20 & 0,566 & 0,120 & 95,3 & 0,9915 & $-0,338$ \\
C-1, C-2 and C-3 & 2,3 & 0,691 & 0,177 & 114,2 & 0,9591 & $-1,101$ \\
Fall of roof & & & & & 0,9695 & $-1,534$ \\
B-1 and B-2 & 3,00 & 0,793 & 0,131 & 194,9 & 0,9540 & $-2,083$ \\
\hline
\end{tabular}

Source: own study

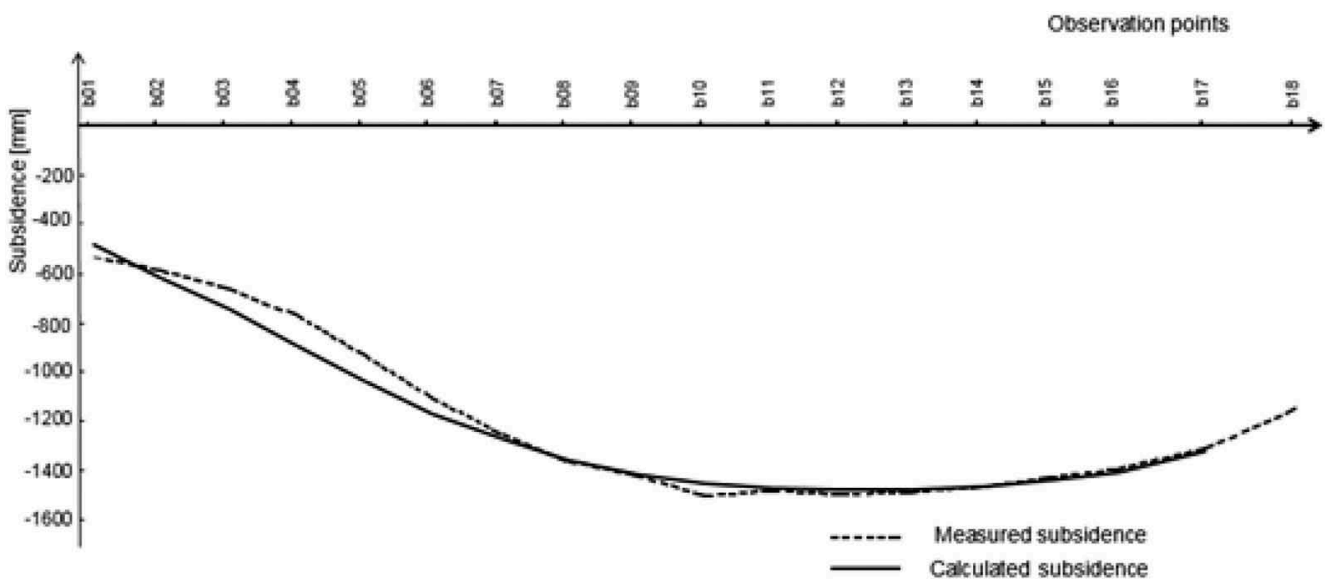

Figure 3. The distribution of measured subsidence and subsidence calculated on the points of the measuring line $\mathrm{b}$ in the region I for the state after exploitations of parcels C1, C2, C3.

Source: own study 


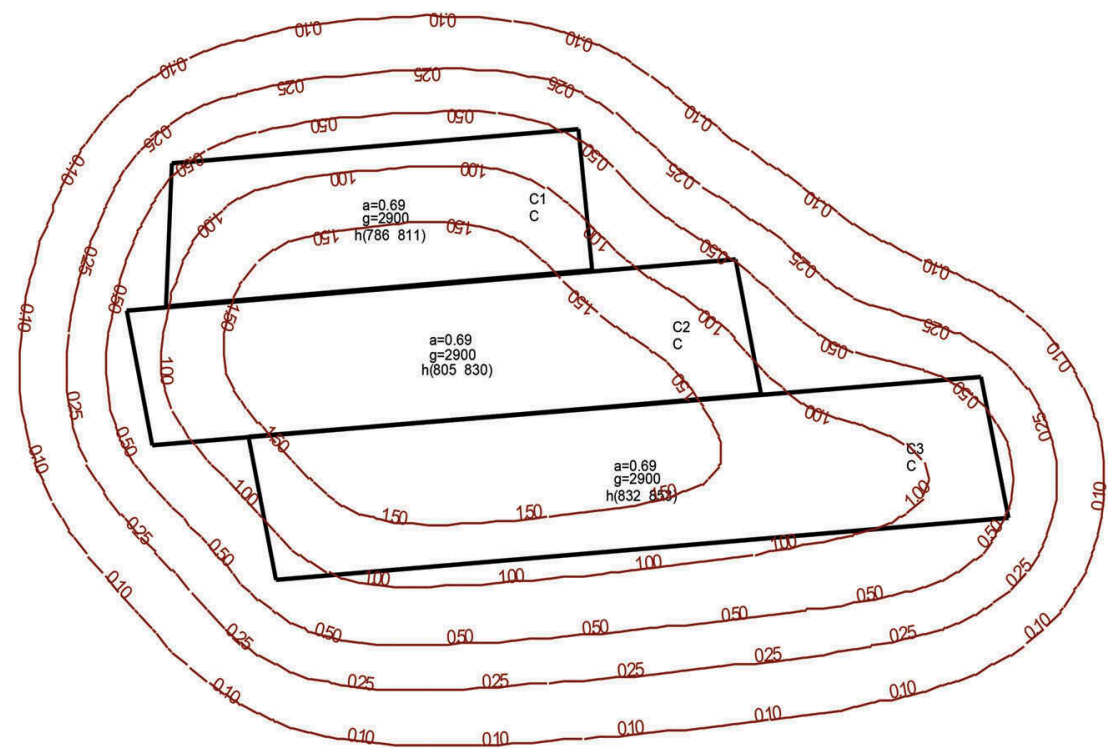

Figure 4. Surface distribution of increments of the subsidence $[\mathrm{m}]$ in region I after exploitation of the parcels $\mathrm{C} 1, \mathrm{C} 2, \mathrm{C} 3$.

Source: own study

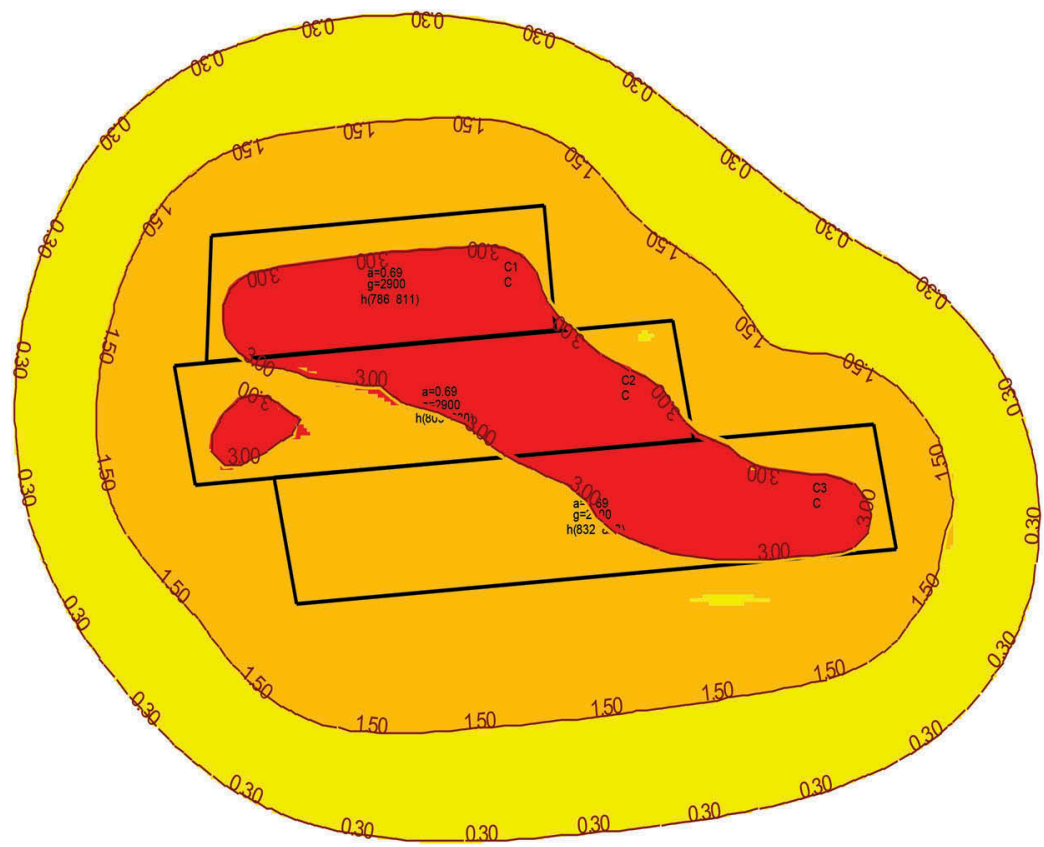

Figure 5. Maximum strain extreme values $[\mathrm{mm} / \mathrm{m}]$ over time - C1, C2, C3 parcels region.

Source: own study

The results of computer simulation of subsidence and strains extreme over time in the region I, assuming the value of forecasting parameters as for fall of roof, are shown in Figures 9, 10. 


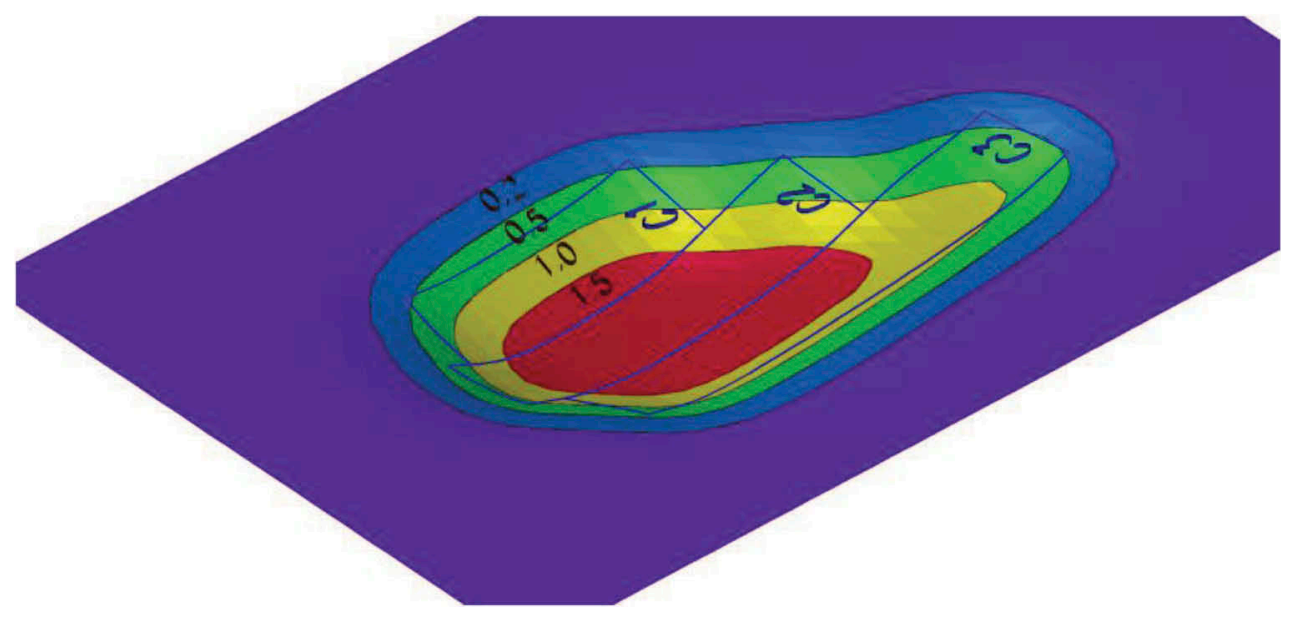

Figure 6. Spatial distribution of subsidence increments - region I, parcels C1, C2, C3.

Source: own study

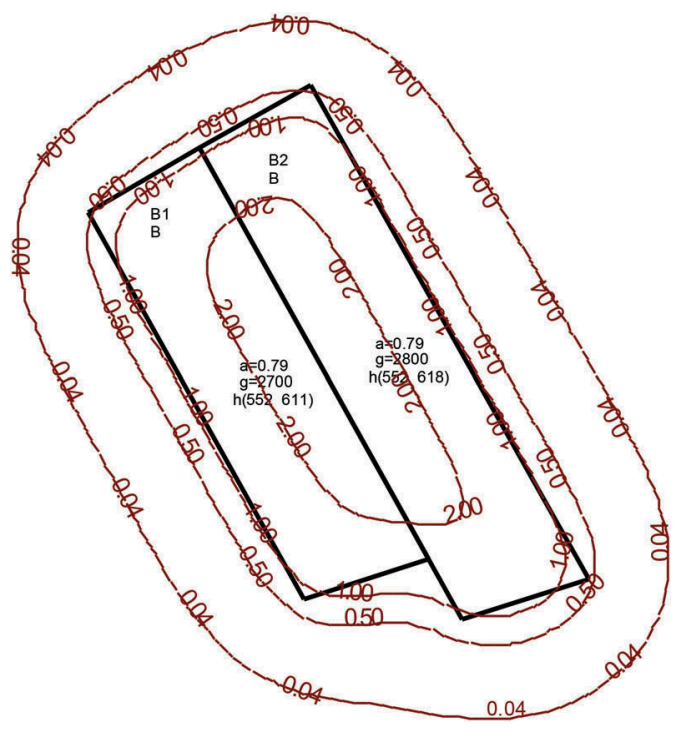

Figure 7. Surface distribution of subsidence increments [m] in region II after exploitation of the parcels B1, B2.

Source: own study

\section{ANALYZES}

A comparative analysis of values of the subsidence coefficient $a$ determined in regions I and II showed that in case of exploiting with sealing of caving gobs, this coefficient ranges from 0.473 to 0.691 and is not less lower than 0.1 than the subsidence coefficient for exploitation with fall of roof.

The value of the coefficient $a$ after choosing the first longwall with sealing of caving gobs was 0.473 , after selecting the first and second longwall with sealing of gobs 0.566 , and after selecting three longwalls it was 0.691 , which confirms the significance of the impact of the 


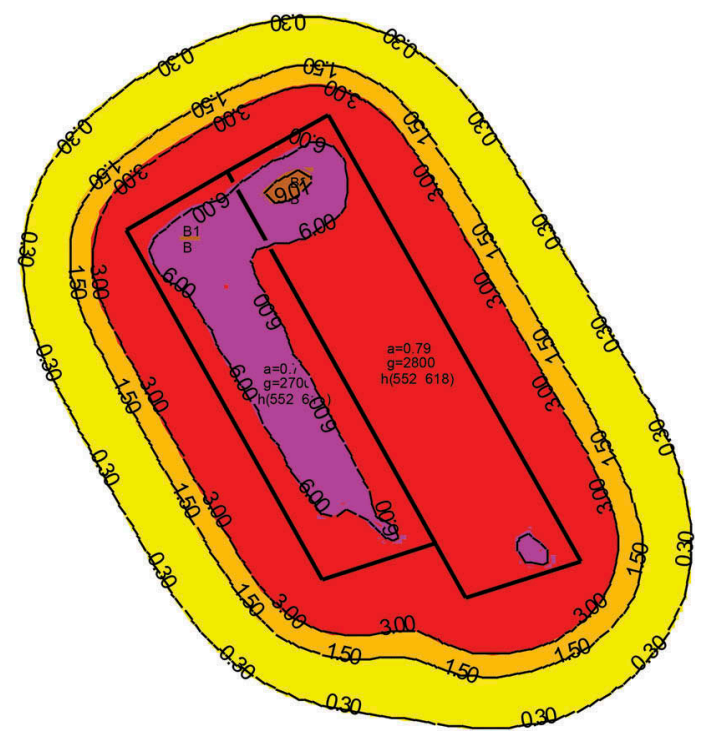

Figure 8. Maximum strain extreme values $[\mathrm{mm} / \mathrm{m}]$ over time in the region II - parcels B1, B2. Source: own study

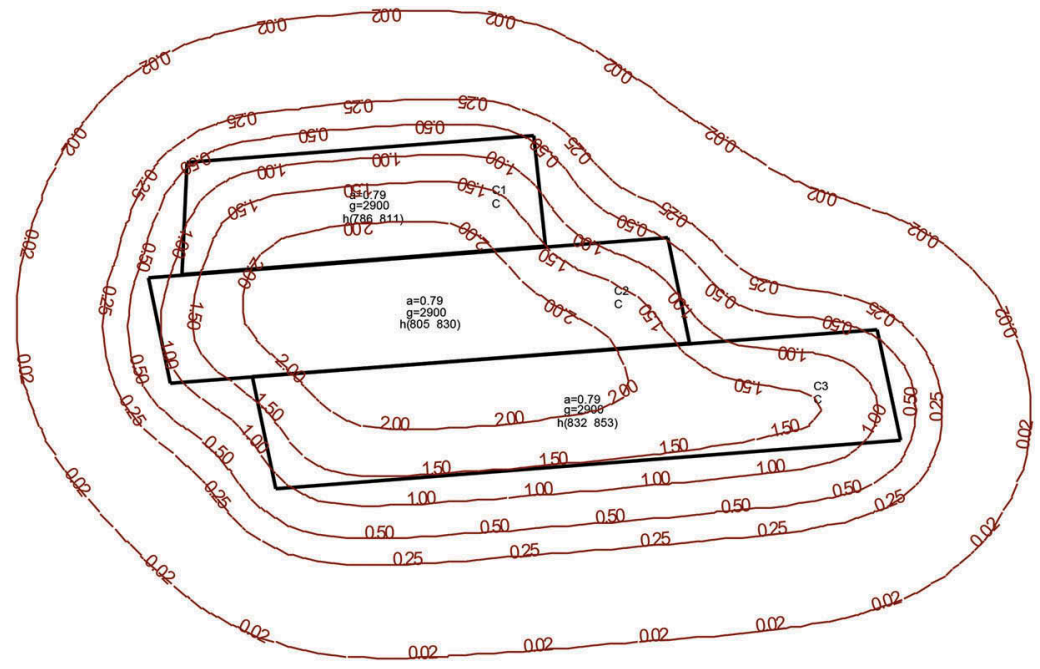

Figure 9. The surface distribution of subsidence increments $[\mathrm{m}]$ in the region $\mathrm{I}$ assuming that $\mathrm{C} 1, \mathrm{C} 2$, C3 parcels are exploited with a longwall system with fall of roof.

Source: own study

volume of extraction on its value. The dependence of the value of the coefficient $a$ on the volume of the extraction can be described by a linear functional dependence in the form presented in Figure 11.

Computer simulations of subsidence for longwalls exploitation with sealing of caving gobs, assuming the values of the parameters of forecasting theory determined for exploitation with fall of roof, showed that using a solution with sealing of caving gobs, the values even up to $20 \%$ lower can be obtained when exploiting without sealing. The maximum value of the subsidence calculated for the exploitation with the fall of roof was $2.00 \mathrm{~m}$. The surface 


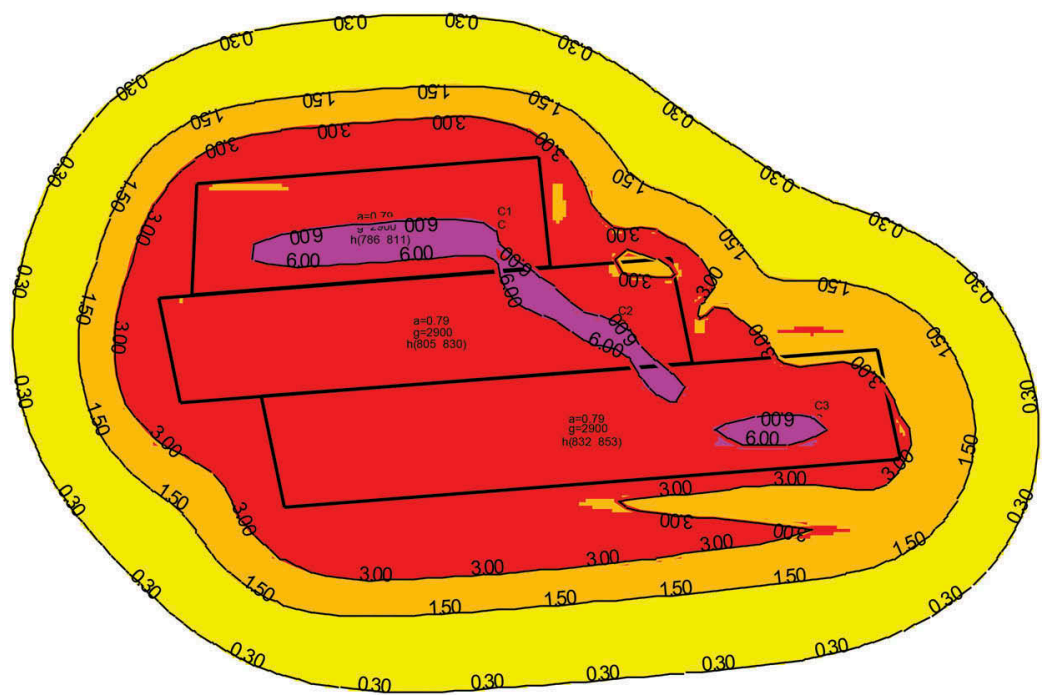

Figure 10. Maximum strain extreme values $[\mathrm{mm} / \mathrm{m}]$ over time in the region I assuming the exploitation of parcels $\mathrm{C} 1, \mathrm{C} 2, \mathrm{C} 3$ with a longwall system with fall of roof.

Source: own study

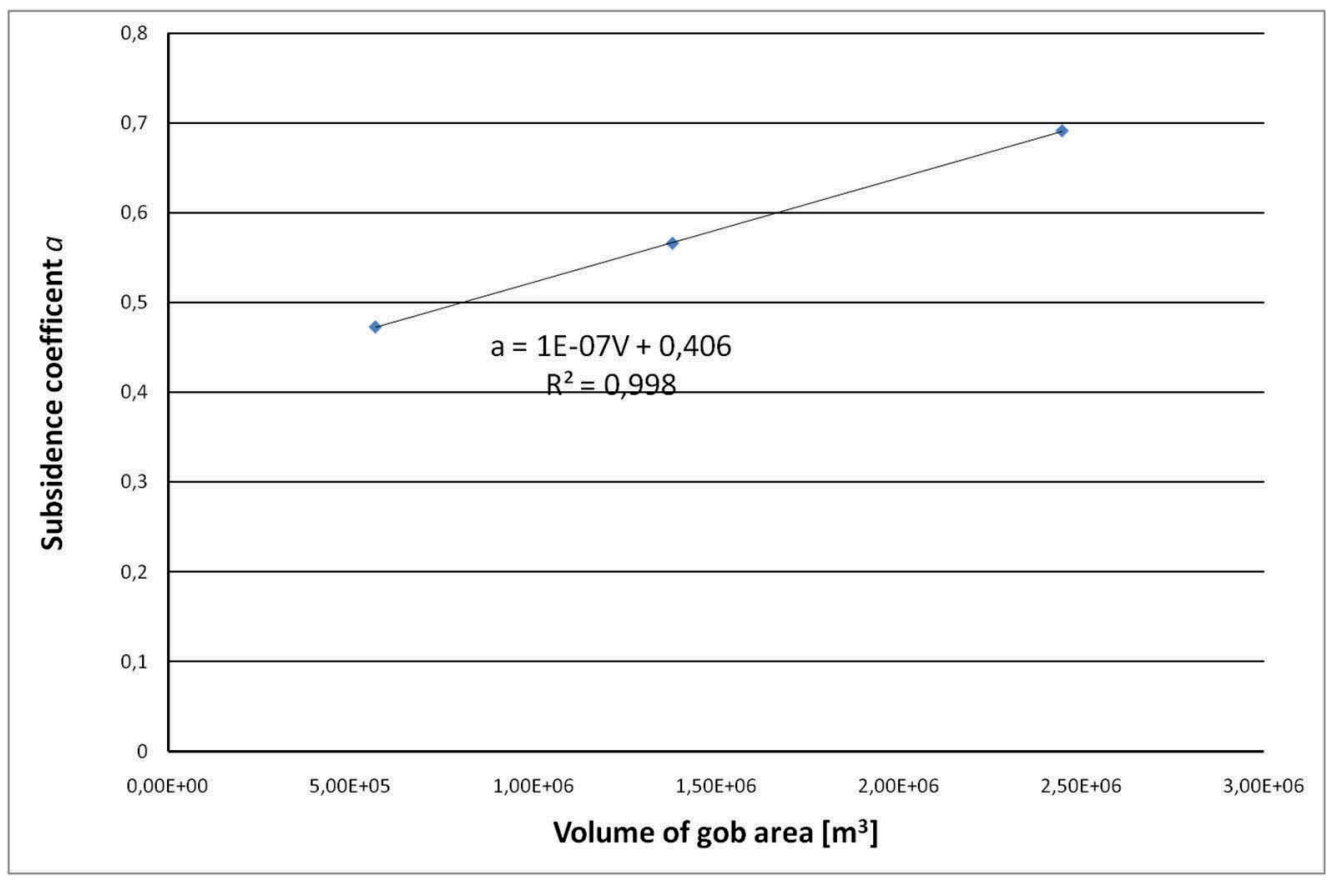

Figure 11. Dependence of the settlement coefficient value $a$ on the selected volume $\mathrm{V}$ of gob area. Source: own study

distribution of differences in the values of subsidence during the analysis period is shown in Figure 12. In the case of extreme strains with the use of sealing of caving gobs solution, the maximum strain extreme values were found to be lower of up to $40 \%$ than the values found 


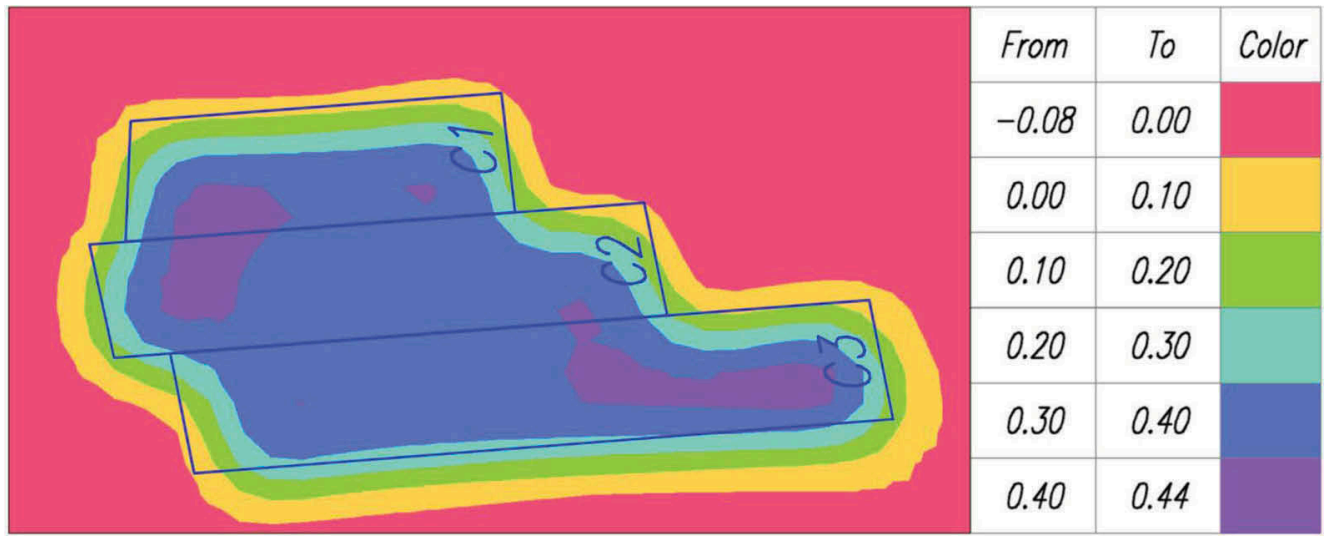

Figure 12. The surface distribution of differences in the increments values of subsidence [m] (gobs sealing - fall of roof) in the region I.

Source: own study

assuming the use of non-sealing exploitation. The maximum value of strains extreme over time for fall of roof exploitation was $5 \mathrm{~mm} / \mathrm{m}$. The surface distribution of extreme strains differences over time is presented in Figure 13.

Further considerations were made in determining the dependence of increments changes of the determined subsidence coefficient $a$ on the degree of sealing gobs defined as the ratio of the height of gobs filling $M$ to the height of exploitation $g$. The relationship between these quantities is shown in Figure 14. The obtained results allow us to assume that increasing the degree of sealing results in a decrease in the subsidence coefficient. In the examined region, when filling about $12 \%$ of the selected space, the value of the coefficient was about 0.47 , which is about $40 \%$ of the value of the coefficient of subsidence with fall of roof that is assumed in the region. However, when $10 \%$ of the selected space is filled, the subsidence coefficient value is about $12 \%$ lower than for exploitation with fall of roof.

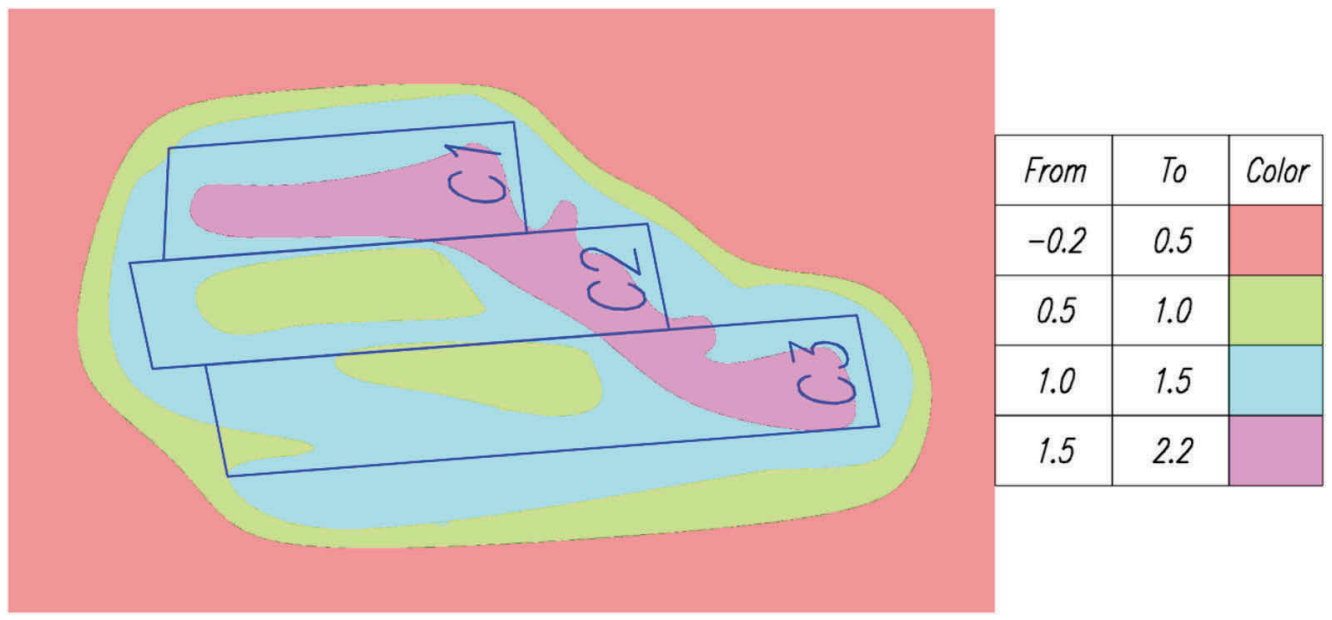

Figure 13. The surface distribution of differences of the values of maximum strains extreme [mm/m] over time (gobs sealing - fall of roof) in region I.

Source: own study 


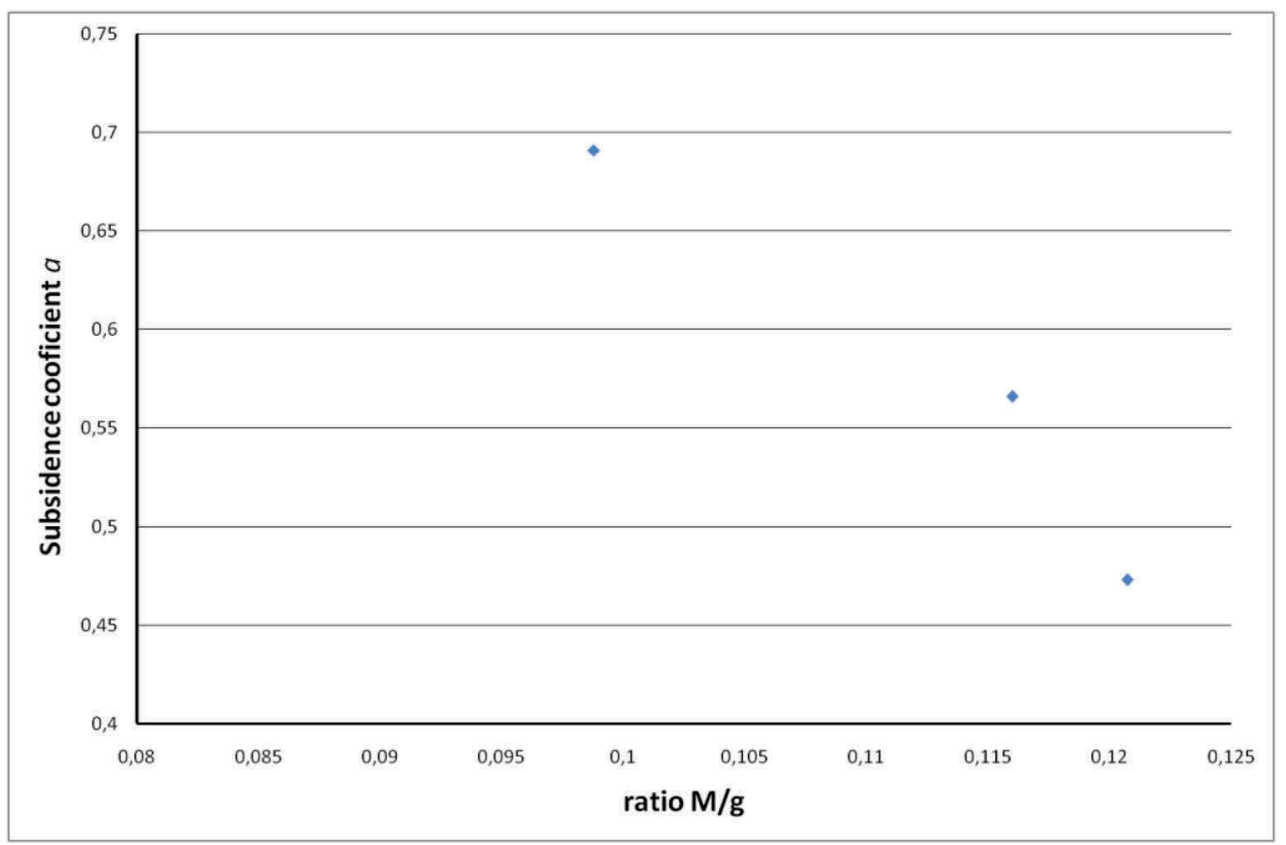

Figure 14. The relationship between the coefficient of subsidence a and the degree of sealing caving gobs. Source: own study

\section{CONCLUSIONS}

Based on the conducted research it can be stated:

- the use of exploitation with sealing of caving gobs significantly reduces the values of mining area surface deformation coefficients. In the example under consideration, the subsidence recorded in the conditions of exploitation conducted with sealing of caving gobs reached values up to a maximum of $20 \%$ lower than with exploitation without sealing, in the case of deformations, the values of maximum strains extreme over time have reached a value up to $40 \%$ lower than without sealing,

- the use of a solution with caving gobs sealing causes the reduce of the value of the subsidence coefficient by at least about 0.1 . Considering the relationships of the calculated degree of sealing with changes in the coefficient a showed that when filled with sealing mixture of about $10 \%$ of the selected space, its value decreases by about 0.12 . At $12 \%$ filling, the coefficient value was as much as $40 \%$ lower than in the case of fall of roof exploitation,

- the dependence of the coefficient a on the extraction volume $\mathrm{V}$ can be described by a linear functional dependence.

Therefore, it follows from the above that in the case of using extraction with gobs sealing, a reduction in the values of deformation rates can be obtained, which should be taken into account at the stage of forecasts of surface area deformations developed for the planned mining exploitation, which is currently not practiced.

The issue that is the subject of the article requires further research, in particular taking into account the parameters of the sealing mixture.

\section{BIBLIOGRAPHY}

Bals, R. 1931/32. Beitrag zur Frage der Vorausberechnung bergbaulicher Senkungen. Mitteilungen aus dem Markscheidewesen 42-43. (in German). 
Beyer, F. 1945. Über die Vorausbestimmung der beim Abbau flachgelagerter Flöze autretenden Bodenverformungen. Postdoctoral dissertation. Berlin. (in German).

Białek, J. 2003. Algorithms and computer programs for the prediction of mining Ground deformation. (Algorytmy i programy komputerowe do prognozowania deformacji terenu górniczego). Gliwice: Silesian University of Technology, 199 pp. (in Polish).

Białek, J. and Sokoła-Szewioła, V. 2012. Short-term approximation of observed subsidence of a mining ground point. (Krótkookresowa aproksymacja zaobserwowanych obniżeń punktu terenu górniczego) Przeglad Górniczy, 68 (8),pp. 148-153. (in Polish).

Budryk, W. 1953. Determining the size of horizontal land strains (Wyznaczanie wielkości poziomych odkształceń terenu). Archiwum Górnictwa i Hutnictwa 1(1). (in Polish).

Dżegniuk. B. 1975. Some non-linear effects in the process of subsidence over mining exploitation. (Niektóre efekty nieliniowe w procesie osiadania nad eksploatacja górniczą). Kraków: The Bulletin of AGH University of Science and Technology, s. Geodezja 34. (in Polish).

Greń, K. 1981. An attempt to include the asymmetry of mining exploitation impacts at horizontal lying of seams (Próba ujęcia asymetrii wpływów eksploatacji górniczej przy poziomym zaleganiu pokładów). Prace Komisji Górniczo-Geodezyjnej. Geodezja 29. Kraków: PAN. (in Polish).

Hejmanowski, R. 2004. Dynamics of mining exploitation from the point of view of mining damage. (Czasoprzestrzenny opis deformacji górotworu wywolanych filarowo-komorowa eksploatacja zloża pokladowego). Kraków: AGH University of Science and Technology Publishing House, issue 131. (in Polish).

Knothe, S. 1953. Equation of the profile of the finally formed subsidence trough. (Równanie profilu ostatecznie wykształconej niecki osiadania). Archiwum Górnictwa i Hutnictwa, 1(1). (in Polish).

Kochmański, T. 1949. Horizontal and vertical movement of a terrain due to mining. (Przesunięcia terenu w pionie i w poziomie pod wpływem odbudowy górniczej). Hutnik, 7-8. (in Polish).

Kowalski, A. 2007. Unspecified mining surface deformations in the aspect of forecast accuracy. (Nieustalone górnicze deformacje powierzchni w aspekcie dokładności prognoz). Katowice: GIG, Prace GIG 871. (in Polish).

Litwiniszyn, J. 1969. On directions of theoretical research on the impact of underground mining exploitation on rock mass movements (O kierunkach badań teoretycznych wpływu podziemnej eksploatacji górniczej na ruchy mas skalnych). Proceedings of the Ist National Symposium on Ochrona powierzchni przed szkodami górniczymi. SITG, WUG. (in Polish).

Ostrowski, J. 2015. Deformations of the mining area (Deformacje powierzchni terenu górniczego). Kraków: AGH University of Science and Technology. (in Polish).

Piotrowski, Z. and Mazurkiewicz, M. 2006. Absorption of caulking of caving gobs (Chłonność doszczelnianych zrobów zawałowych). Górnictwo i Geoinżynieria (3, .pp, 37-45. (in Polish).

Plewa et al. - Plewa, F .Mysłek, Z. and Strozik, G. 2008. The use of energy waste to solidify rock debris (Zastosowanie odpadów energetycznych do zestalania rumowiska skalnego). Polityka energetyczna 11(1), pp. 351-360. (in Polish).

Popiołek, E. and Ostrowski, J. 1981. An attempt to determine the main reasons for the discrepancy of forecasted and observed post- mining deformation rates. (Próba ustalenia głównych przyczyn rozbieżności prognozowanych i obserwowanych poeksploatacyjnych wskaźników deformacji). Ochrona Terenów Górniczych (58). (in Polish).

Praca zbiorowa pod redakcją J. Kwiatka (Collective work edited by J. Kwiatek). 1998. Protection of building structures in mining areas (Ochrona obiektów budowlanych na terenach górniczych). Katowice. (in Polish).

Rutkowski, T. 2019. Impact of caulking of caving gob on deformation of the mining area of the RudaRuch - Pokój coal mine (Wpływ doszczelniania zrobów zawałowych na deformacji powierzchni terenu górniczego KWK Ruda - ruch Pokój). Przegląd Górniczy 2, pp. 13-20. (in Polish).

Sokoła-Szewioła, V. and Kowalska-Kwiatek, J. 2013. A complex method of indication of parameters of the model describing the mining area depression in time (Kompleksowa metoda wyznaczania parametrów modelu opisującego obniżenia terenu górniczego w czasie). Przeglad Górniczy 69(3), pp. 142-148

Sroka, A. 1999. Dynamics of mining exploitation from the point of view of mining damage (Dynamika eksploatacji górniczej z punktu widzenia szkód górniczych). The Mineral and Energy Economy Research Institute of the Polish Academy of Sciences, Studia, Rozprawy, Monografie 58. (in Polish).

Świnder, H. 2014. Influence of selected organic compounds on the parameters of mixtures injected into goaf caving equipment (Wpływ wybranych związków organicznych na parametry mieszanin zatłaczanych do zrobów zawałowych). Przegląd Górniczy 12, pp.67-73. (in Polish).

Szpetkowski, S.1995. Forecasting impacts of seam deposits exploitation on the rock mass and surface (Prognozowanie wplywów eksploatacji złóż pokładowych na górotwór i powierzchnię terenu).Katowice: Śląskie Wydawnictwo Techniczne. (in Polish). 
Yu Yang, Xie-xing Miao, Wen-sheng Liu and Xing-hua Li. 2008. Deformation of mining caving zone grouting compound rock under overlying strata pressure. Journal of Coal Science and Engineering (China) 14, pp. 594-596.

Zych et al. 1993- Zych, J. Żyliński, R. and Strzałkowski, P. Impact of caving gobs caulking on the amount of surface deformation (Wpływ doszczelniania zrobów zawałowych na wielkość deformacji powierzchni). Proceedings of the Conference on II Dni Miernictwa Górniczego i Ochrony Terenów Górniczych. GIG, pp.307-311. (in Polish).

Zych, J. 1987. A method of forecasting the impacts of mining exploitation on the surface area, taking into account the asymmetrical course of the deformation process. (Metoda prognozowania wpływów eksploatacji górniczej na powierzchnię terenu uwzględniająca asymetryczny przebieg procesu deformacji). The Bulletin of Silesian University of Technology, s. Górnictwo, 164. (in Polish). 